\title{
The Impact of Trauma on Vietnamese Refugees in Robert Olen Butler's A Good Scent from A Strange Mountain (1992) and Viet Thanh Nguyen The Refugees (2017)
}

\author{
By \\ Dr. Sherine Abdelghafar* \\ sherine_abdelghafar@aun.edu.eg
}

\begin{abstract}
After the collapse of the South Vietnamese government, thousands of people fled away from their own country. Eventually, by the late 1980s and early 1990s, many individuals made their way to the United States in order to escape intolerable conditions in their countries and to seek a better life. There were three waves of Vietnamese immigration; the most significant and complicated was the third wave, which came after 1982; it included different types of Vietnamese refugees. This paper attempts to study the challenges Vietnamese refugees have faced in the U.S. Selected stories from the collections of A Good Scent from a Strange Mountain (1992) by Robert Olen Butler, and The Refugees (2017) by Viet Thanh Nguyen, will be studied in the light of the refugee trauma theory. The Vietnam War was a unique war in history and, thus, called for an equally distinctive representation in literature. The stories, in both collections, are connected by the common experience of characters that have survived the war in Vietnam and found their way to America. Both writers offer a diverse group of characters - some protagonists are Vietnamese, others are American, but most are Vietnamese-American. Through the different stories of their characters, Butler and Nguyen explore questions of identity. They focus on how it feels and what it means to be a refugee. They demonstrate as well the different ways by which refugees respond to their traumatic experiences.
\end{abstract}

Keywords: Saigon -Vietnamese refugees -trauma theory - identity lost past

* Lecturer - English Department - Faculty of Arts.

(The Impact of Trauma on Vietnamese Refugees in ...)Dr Sherine Abdelghafar 


\section{INTRODUCTION}

"For all refugees, everywhere"

(Nguyen, The Refugees)

After the fall of Saigon at the end of the Vietnam War in 1975, millions of Vietnamese left their home country and fled to the United States in search of new opportunities. In The 1975 refugees: their first five years in America, Baker and North declare:

The United States had made a substantial commitment to our [Vietnamese] allies in Indochina and lost. Millions of Americans had worked and fought in VN; the U.S. poured tens of billions of dollars into the conflict; and most of the social and political energies of a generation of Americans were spent debating our role in that war. Fearing a Communist blood bath, the U.S. welcomed its defeated allies as refugees. (22)

However, the Vietnamese refugees carried traumatic visions with them as they tried to make their way in 'their' new country. In Nothing Ever Dies, Nguyen writes,

The mood in the handful of room, denoted in the captions and narratives, is one of sorrowful memory and mourning for dead soldiers, forgotten heroes, and what I think of as oceanic refugees, a term that lends more nobility to the 
suffering and heroism of those whom the Western Press called the "boat people." (36)

He adds,

They [the Vietnamese] have lost their countries of origin, either by choice or circumstance, and their hosts often see them as others. This sense of loss and otherness inflects their memories differently from the memories of majorities. (38)

Since then, trauma has become the subject of an enormous body of literary works. Claire Stocks points out, "it is [only] since the fall of Saigon which ended the Vietnam War in 1975 that trauma has become the subject of a fairly substantial body of theoretical and literary works" (71).

The refugees seldom discuss the war that has shaped their 'identities'; instead, they keep living in the past. Viet Thanh Nguyen recalls the day when his mother, a refugee, returned home after a long day work and took him on a ride:

Perhaps I was eleven or twelve, maybe younger. We drove silently in the night, the windows rolled down for the cool breeze. The radio was off. My parents never listened to the radio in the car. She would not speak to me, or perhaps she did and I did not listen to her or do not recall. Even if she did speak to me, I do not know what I would have said. We drove into the hills in silence and then we returned home. Perhaps this

(The Impact of Trauma on Vietnamese Refugees in ...)Dr Sherine Abdelghafar 
was her way of reaching out to me, the boy who had lost his mother tongue, or who had cut it off in favor of his adopted tongue. Perhaps she simply needed a few minute away from work and my father, whom she saw every minute of the day. What did she think of, what did she remember. Now I cannot ask. Her memories are vanishing and her body is slow to obey her. She will not be counted as one of the war's casualties, but what else do you call someone who lost her country, her wealth, her family, her parents, her daughter, and her peace of mind because of the war. (Nothing Ever Dies 239)

The refugees seek RECOGNITION, which means they be accepted as American citizens not as refugees. They want to be seen as "a part of the place in which" they "live or call home," where they "claim belonging and . . . ask for citizenship" (61).

The movement from the homeland to the adopted land, as refugees, and finally the reconciliations, marks much of the Vietnamese literature. However, this paper aims at reflecting the suffering of the Vietnamese refugees, and the way the Vietnam War has changed their lives.

\section{METHDOLOGY}

This paper examines, in light of Cathy Caruth's modern trauma theory, Robert Butler's A Good Scent from a Strange Mountain (1992) and Viet Thanh Nguyen's The Refugees (2017) as they tackle the issue of the Vietnamese problems

(The Impact of Trauma on Vietnamese Refugees in ...)Dr Sherine Abdelghafar 
within the bodies and minds of the Vietnamese themselves. Thus, the study will give an overview of the trauma theory and will show how both Butler and Nguyen depict the impact of trauma on the Vietnamese refugees but through different points of view. The refugees depicted are what E. F. Kunz calls 'acute refugees.'

\section{A THEROTICAL UNDERSTANDING OF THE REFUGEE TRAUMA}

\subsection{Who is a Refugee?}

3.1.1. Etymology. Etymologically, the word 'refugee' is derived from the French refugié (i.e. 'to take shelter'); from Old French refuge (i.e. hiding place); from Latin refugium (i.e. a place to flee back to). However, the word 'refugee' has a recent origin in English, where it appeared in 1685 when a group of French migrants fled their country to escape religious persecution. It meant 'one seeking asylum' but it developed later on in 1914 to mean 'one fleeing home.' (Harper)

3.1.2. UNHCR Definition. According to Article $1 \mathrm{~A}$ of the 1951 Convention relating to the Status of Refugees, a refugee is someone who: "is outside his or her country of nationality or habitual residence; has a well-founded fear of persecution because of his/her race, religion, nationality, membership in a particular social group or political opinion; and is unable or unwilling to avail himself/herself of the protection of that country, or to return there, for fear of persecution" (UNHCR 3).

(The Impact of Trauma on Vietnamese Refugees in ...)Dr Sherine Abdelghafar 
Unfortunately, the world has witnessed an increasing number of people who were forced to flee their homes and leave their families behind in order to escape the violence, persecution and human rights abuses (UNHCR). Many of these refugees have suffered incidents of extreme trauma including death, war, and loss.

\subsection{Theory of Trauma}

3.2.1. Kunz's Kinetic Model of Refugee Theory. Kunz's Kinetic Model of Refugee Theory offers two types of refugees: anticipatory and acute. Anticipatory refugees are those people who leave their home country "before the deterioration of the military or political situation" prevent their "orderly departure." They arrive in the country of settlement prepared for their new lives; they are accompanied by their families, know the language of their new land, and have some financial resources to "re-enter the trade or profession" (Kunz 131-32).

On the contrary, acute refugees "flee either in mass or, if their flight is obstructed, in bursts of individuals or group escapes, and the primary purpose is to reach safety in a neighboring or nearby country which will grant them asylum." Unlike the anticipatory refugees, they are not prepared for this new life; all they are seeking is survival. Mostly, acute refugees experience traumatic incidents; their situation deteriorates to the point that they find it "intolerable to stay any longer in the country of asylum" from where they originally intend to return back to their home country (132). However, as time passes, the refugees realize "there will be

(The Impact of Trauma on Vietnamese Refugees in ...)Dr Sherine Abdelghafar 
no victorious return" (133). Thus, they find themselves forced to cope with survival in their new home.

3.2.2. Cathy Caruth's Trauma Theory. In its general definition, the term 'trauma' "is not an event itself, but rather a response to a stressful experience in which a person's ability to cope is dramatically undermined" (Cole et al. 18). More specifically, Caruth describes 'trauma' as 'an overwhelming experience of sudden or catastrophic events in which the response to the event occurs in the often delayed, uncontrolled repetitive appearance of hallucinations and other intrusive phenomena" (11).

Caruth argues, "trauma is not locatable in the simple violent or original event in an individual's past, but rather in the way that its very unassimilated nature - the way it is precisely not known in the first instance-returns to haunt the survivor later on" (4). She claims that the refugees struggle to fully comprehend and absorb the traumatic events they faced: "The historical power of the trauma is not just that the experience is repeated after its forgetting, but that it is only in and through its inherent forgetting that it is first experienced at all" (17). Caruth goes on to state that trauma is connected as well to repetition of events:

[T]rauma is described as the response to an unexpected or overwhelming violent event or events that are not fully grasped as they occur, but return later in repeated flashbacks, nightmares, and other repetitive phenomena. Traumatic experience, beyond the psychological dimension of suffering it involves, suggests a

(The Impact of Trauma on Vietnamese Refugees in ...)Dr Sherine Abdelghafar 
certain paradox: that the most direct seeing of a violent event may occur as an absolute inability to know it; that immediacy, paradoxically, may take the form of belatedness. The repetitions of the traumatic event - which remain un available to consciousness but intrude repeatedly on sight - thus suggest a larger relation to the event that extends beyond what can simply be seen or what can be known, and is inextricably tied up with the belatedness and incomprehensibility that remain at the heart of this repetitive seeing. (91-92)

Caruth suggests that, though the refugee has not fully experienced the trauma, he will resort to repetition in order to try to adapt to the post-traumatic life. Post-traumatic stress disorder, or PTSD, may be defined as "an overwhelming experience of sudden or catastrophic events in which the response to the event occurs in the often uncontrolled, repetitive appearance of hallucinations and other intrusive phenomena." (57-58) Therefore, not experiencing the traumatic event in time is what causes the repetition of the event in the mind of the refugee. The traumatic event is repeated in the form of dreams: "These dreams are endeavoring to master the stimulus retrospectively, by developing the anxiety whose omission was the cause of the traumatic neurosis" (Freud 26). As a result, the traumatic survivor might find himself forced to confront the event repeatedly. 


\section{ANALYSIS}

Robert Olen Butler, who served as both a translator and a spy during the Vietnam War, published A Good Scent from a Strange Mountain in 1992. Butler won the Pulitzer Prize for his collection in 1993. The stories in this collection are narrated in the first person from the perspective of different Vietnamese refugees who fled to Louisiana, America. The stories exhibit the difficulties Vietnamese refugees have in their "new" home. The plots of the stories are interrelated, serving the main theme of the book, which is to depict cultural differences between the Vietnamese and the Americans. Each story is narrated by a different Vietnamese refugee. Therefore, by focusing on the experience of Vietnamese refugees who attempt to understand the cultural difference in the U.S., the stories in A Good Scent from a Strange Mountain elucidates Caruth's idea that trauma itself may provide "in a catastrophic era a link between cultures" (56). Besides, the refugees represented in these stories are examples of what Kunz categorize in his theory as 'acute refugees.'

Before the publication of A Good Scent from a Strange Mountain, Butler had "established his reputation as a writer of Vietnam fiction." This "categorization" annoyed Butler. His earlier works received negative criticism because they were narrated from the points of view "that was not his own - that is, he took on the role of a Vietnamese person." However, the publication of A Good Scent from a Strange Mountain "silenced his critics," who agreed on "the power of Butler's prose and his haunting evocation of the Vietnamese

(The Impact of Trauma on Vietnamese Refugees in ...)Dr Sherine Abdelghafar 
voice" (Gale). Richard Eder asserts, "Butler writes essentially, [. . . ], what it means to lose a country, to remember it, and to have the memory begin to grow old. He writes it as if it were his loss too" (3). Laura Dawkins asserts that "Butler's characters often understate - even fail to acknowledge - the profound psychological repercussions of their diverse experiences of loss, displacement, and exile." However, he elaborates "the variety of ways in which Butler's narrators register their experience of war and exilee.g. by telling stories, conversing with ghosts, preserving relics, displacing their own emotions onto others-suggest the author's familiarity with contemporary trauma theory, specifically its emphasis upon survivors' belated, oblique, and often enigmatic responses to traumatic events" (34).

While Butler wrote about refugees in Louisiana, Nguyen's focus was on refugees in Little Saigon of Orange Country in California. Growing up in San Jose in California, Nguyen felt split in two as he was both a refugee and an American. He declares, "regardless of what George Bush said regardless of what Jesse Jackson said. I was an American and I was also a refugee" ("Viet" 00:14:48).

Nguyen became a refugee in 1975 when he was only four years old. His family fled the country, ending up in a refugee camp called Fort Indiantown Gap in Pennsylvania. Nguyen remembers being taken away from his parents by a sponsor. This painful experience has always remained with Nguyen, and perhaps determined his life: "I imagine how painful that experience must have been for me-and also for my parents. That's where my memory begins. I've never forgotten being 
a refugee-because of that trauma" (Call Me). Thus, as Nguyen states, "Rather than myself seeking out the past, the past has sought me out, something I have felt ever since I came to the US as a refugee from Vietnam" (Just Memory 1).

In an interview, Nguyen says he does not intend to avoid his identity as a refugee. Furthermore, he insists on being called a 'refugee,' not an 'immigrant.' He distinguishes between both terms as follows:

The immigrant idea in America is very strong. We call ourselves "a nation of immigrants"; it's a part of our mythology that immigrants come here and achieve the American dream. Even at this moment in history, where the xenophobic attitudes that have always been present are reaching another peak, even people who don't like immigrants nevertheless believe in that immigrant idea. But refugees are different. Refugees are unwanted where they come from. They're unwanted where they go to. They're a different legal category. They're a different category of feeling in terms of how the refugees experience themselves. If you call yourself an immigrant here, you fit. People will want to hear your heartwarming story about getting to this country. If you say you're a refugee, that's the quickest way to kill a conversation, because people can't relate to that. It's easy for someone like me to pass himself off as an immigrant, to pretend to be an immigrant, but if I do that, I

(The Impact of Trauma on Vietnamese Refugees in ...)Dr Sherine Abdelghafar 
feel like I'm not speaking the truth. I feel that it's necessary for people like me, who have benefited from being a refugee, to acknowledge our existence as such and to advocate for the new refugees today. (Call Me)

Nguyen thus calls the refugees to recognize the United States as the land of slavery and colonialism, not just the land of dreams. He attempts to demonstrate the contradictions the refugees confront in his work. He realizes that "Vietnamese people the Vietnamese Americans and refugees that I knew were full of stories they could never stop telling stories and these stories were saturated with pain and bitterness and loss and melancholy and regret" ("Viet" 00:16:25). He insists that the Americans would never recognize the Vietnamese as citizens: "in the American imagination the only place for the Vietnamese was to be in the background was to be silenced." However, Nguyen would not accept for the refugees to be marginalized. He wants to write stories about their complexities in order to "bring them to the forefront of the American imagination." (00:16:41)

To achieve this, Nguyen visited Vietnam in the period from 2002 to 2012 for about five or six times. He even spent a whole year there. He studied the Vietnamese language, history, politics, and memory. He wanted to know how the refugees really felt. Nguyen believes the Vietnamese 'history still demands an ongoing engagement with what that war meant, if we are not to concede its meaning to revisionist, national agendas in the United States.' Viet Thanh Nguyen notes, "So much is told about Viet Nam, and so little is

(The Impact of Trauma on Vietnamese Refugees in ...)Dr Sherine Abdelghafar 
understood" (Speak of the Dead 13). Thus, he dedicated the book, which followed his Pulitzer Prize-winning novel, The Sympathizer, to "all refugees, everywhere." In The Refugees, Viet Thanh Nguyen gives voice to lives led between two worlds, the adopted homeland and the country of birth. Just like Butler's refugees, Nguyen's are quite accurate examples of 'the acute refugees,' and they also emphasize Caruth's idea of the "link between cultures" (56).

Through the different points of view of their characters, both Butler and Nguyen attempt to show how it feels to be a refugee. Most of the stories in both collections follow the lives of Vietnamese refugees who escaped Vietnam and settled in the United States. These stories tackle the cultural distinctions between the Americans and the Vietnamese, leading one to wonder whether the refugees have been able to adapt to their new lives or are caught between the American and Vietnamese cultures.

\subsection{The Ghost as a representation of the past}

James Berger notes, ghosts or "revenants" are "among the most common and effective figures for the return of trauma in recent fiction" (72). One common theme between Butler and Nguyen is the use of the ghost to represent the past. Nguyen asserts, "Common in the world of refugees are memories and stories of the dead, the missing, and the ones left behind, those relatives, friends, and countrymen facing the consequences escaped by the refugee. In some cases, the refugee may even benefit from telling about those consequences and the ghosts of their past" (Speak of the Dead 9). Yen Le Espiritu declares that we must "become

(The Impact of Trauma on Vietnamese Refugees in ...)Dr Sherine Abdelghafar 
tellers of ghost stories" when we speak of the war in Viet Nam and its aftermath (xix)

In Butler's "A Ghost Story," the narrator begins his story by declaring that he has "a special story to tell, a story about ghosts" (111). John Berger clarifies that the "immersion in or haunting by a traumatic event can be countered by narrative. Instead of allowing the trauma to return on its own terms, we recall the trauma in a narrative of our own framing" (Butler 72). The narrator tells - to strangers on a bus - the story of the ghost of the beautiful Miss Linh, who appears to rescue men from death, then returns later to eat them. The narrator claims that this story is true and that he knows the girl. The events of the story take place during the Vietnam War. The narrator recalls that, one night in April 1975 in Saigon, where "the communists were already in the outskirts of the city" (121) and while he was trying to escape the crowd, an American car from the embassy approached him. He got into the car to find Miss Linh inside. She had saved him, but this gave him "no peace of mind". However, to his surprise, Miss Linh has left him alone. Perhaps, she did not eat him, but she took him away to America. Thus, instead of being haunted by the ghost of Miss Linh, he is now haunted by the ghost of Vietnam -the ghost of the past. He (himself) has turned into a ghost in America:

Are you confused again, my round-eyed friend? Look at me, look where I am, listen to how I speak compulsively to strangers, even strangers from this alien land, listen to the kind of treatment I expect even now, even from you

(The Impact of Trauma on Vietnamese Refugees in ...)Dr Sherine Abdelghafar 
who pretended to listen to me this long with interest. How do I know the major's story is true? Because as I sat in the darkness of the limousine and it drove away, I looked out the window and saw Miss Linh's tongue slip from her mouth and lick her lips, as if she had just eaten me up. And indeed she has. (123)

Dawkins asserts, "Concluding the story with a description of his own encounter with the deadly apparition, who helped him escape to the United States at the end of the war by whisking him into a limousine filled with American dignitaries, the narrator evokes his painful experience of being swallowed up by a powerful foreign entity." He adds, 'the 'ghost' in 'A Ghost Story' emerges as a figure for the narrator's own war trauma, displaced onto the fictional 'major' in his tale and communicated to his audience as a 'true,' symbolically significant event" (40).

Narrated in the first person, "The Black-Eyed Woman" centers on a thirty-eight-year-old unnamed ghostwriter. The narrator is a ghostwriter because she is haunted by the ghost of her own past. She says, "Looking back however, I could see that we had past our youth in a haunted country." Nguyen remarks, "Those who remember the trauma and the suffering that they've been through, they find it very hard oftentimes to let go." While writing the memoir of someone else, she remembers the trauma of her childhood. Here, Nguyen uses the flashback technique to recount the story of the narrator. The ghostwriter remembers/recounts the day she had to flee Vietnam along with her family when she was thirteen years

(The Impact of Trauma on Vietnamese Refugees in ...)Dr Sherine Abdelghafar 
old. Escaping by boat, the family was attacked by pirates, who killed the ghostwriter's older brother and then raped her. Since then, the ghostwriter feels guilty as her brother was killed while protecting her from the pirates. She bemoans the fact that she was the one who got to live while her brother was the one who died. However, the ghost of her brother, who keeps visiting her, eases her guilt by telling her she died too on that day. When she asks him, "Why did I live and you die?" He replies, "You died too. You just don't know it." (Refugees 17) As Caruth points out, "In modern trauma theory [... ], the repetition of the traumatic experience in the flashback can itself be retraumatizing; if not life-threatening, it is at least threatening to the chemical structure of the brain and can ultimately lead to deterioration" (63).

Nguyen here shows that, though the ghostwriter escaped to the United States, she is still a refugee. Whenever she goes, her past haunts her, and each new place is invaded by her past experience. She is repeatedly denied any place of refuge from trauma: "I had not forgotten our nameless blue boat and it had not forgotten me" (14). She tries to escape her past by engaging herself in writing the memoirs of another man named Victor Devoto. It seems that the narrator wants to forget what she has been through before settling in the United States, but at the same time does not want the memories of her brother to fade away. However, she has to confront her past in order to be able to move on. Near the end of the story, and during one of the visits of the ghost of her brother, the ghostwriter weeps, finally able to grieve for the loss of her brother as well as for the time they could have spent together if he was still alive. At that moment, the

(The Impact of Trauma on Vietnamese Refugees in ...)Dr Sherine Abdelghafar 
ghostwriter resolves to move forward, and put the past behind her. She decides to write her own book, a book of 'ghost stories' in which she is to recount the stories of the misplaced lives of the refugees. Once she is able to deal with her trauma, the ghost of her brother disappears. The ghostwriter concludes,

As they [ghosts] haunt our country, so do we haunt theirs. They are pallid creatures, more frightened of us than we are of them. That is why we see these shades so rarely, and why we must seek them out. The talismans on my desk, a tattered pair of shorts and a ragged T-shirt, clean and dry, neatly pressed, remind me that my mother was right. Stories are just things we fabricate, nothing more. We search for them in a world besides our own, then leave them here to be found, garments shed by ghosts. (21)

For Nguyen, stories are real and keep the past alive. He declares, "The ghost, which we may think of as a fiction, stands in for the fact that this past actually is material and substantive for many of us" (Stories) Nguyen uses ghosts to argue for the importance of the past and to show that, the refugees, like ghosts, are haunted by their memories.

\subsection{The Other}

Vickroy states, "The environment of social relations and cultural values can be a source of trauma or a force that silences victims out of denial or guilt. It can create veils of

(The Impact of Trauma on Vietnamese Refugees in ...)Dr Sherine Abdelghafar 
illusion, attempts to mask or reinterpret behaviors that induce trauma" (131). Both Butler and Nguyen show how a Vietnamese refugee may suffer feelings of guilt, shame, or illusions as a response to his traumatic incident. This is shown in two of their stories.

The events of Butler's story, "Open Arms," take place during the war. It tells the story of Đăng Van Thâp, a former Communist who switched allegiances when Viet Cong soldiers killed his wife and children. He works now as a Vietnamese interpreter with the Australian army. The story's narrator, who relates his wartime experience, is assigned to interrogate Thăp. Though feeling distrustful of Thăp's conversion, the narrator for a moment feels a kind of empathy towards him. However, he implicitly fears the tainting influence of the Thap's trauma: "the idea of our opening our arms to him, exposing our chests, our hearts, truly frightened me" (4-5). He believes that Thap is a "ghost" who can "reach into that chest of yours and pull out not only your heart but your soul as well" (5).

The Australian soldiers one day take him to see an X-rated movie. Disgusted, he murders an Australian soldier and kills himself. Butler here wants to show that perhaps he remembered his dead wife. The narrator ultimately admits that Thâp's violent response "is largely provoked by his individual bereavement, since the films both mock his impotent desire and evoke the memory of his lost wife" (Dawkins 43-44). The narrator illustrates, "These films he [Thap] saw [ . . ] brought the feel of his wife to him, [ . . ] I felt bad for Thâp, his wanting a woman, wanting his wife, his

(The Impact of Trauma on Vietnamese Refugees in ...)Dr Sherine Abdelghafar 
being drawn by that very yearning to a vision of her body as ashes now and bits of bone" (13). The narrator's repression of grief for the loss of his wife signifies, as Dawkins points out, "the frequent tendency of trauma survivors to displace or deny-from fear of the unleashed power of their own emotions - their personal suffering" (44). As the narrator admits, “Thâp's desire for his wife had made him very unhappy. But it alone did not drive him to the final act. That was a result of a history lesson. [ . . . ]. The fact that the impurity of the West had touched Thâp directly, had made him feel something strongly for his dead wife, had only made things worse. He'd had no choice" (14). It seems that Thâp becomes obsessed with finding ways to kill himself; in fact, it becomes a way of coping with trauma. These points exhibit Thâp's reflection on traumatic suffering and trauma continues to influence his entire experience.

Narrated in the third person, the story of Nguyen's "The Other Man" focuses on Liem, an eighteen-year-old Vietnamese refugee who flees Vietnam by boat after the fall of Saigon, leaving his family there, and seeking refuge in the United States. As he lands in San Francisco, Liem finds "himself hesitating at the gate, anxiously scanning the strange faces" (Refugees 23). He feels impressed by what he sees: "The sight nearly overwhelmed Liem with relief and gratitude, for no one had ever called him 'mister' before" (24). He is placed in the San Francisco home of an older British man named Parrish Coyne. Liam is shocked when he finds out that Parrish is involved in a relationship with a younger student from Hong kong named Marcus Chan. He is stunned by the fact that he had never seen an open

(The Impact of Trauma on Vietnamese Refugees in ...)Dr Sherine Abdelghafar 
relationship like this before. However, he tries to ignore this fact by keeping himself busy. He gets a job, and makes an effort to improve his English language. A few months later, Parrish leaves on a trip to Washington; Liem and Marcus spend the weekend together whereby the end of the weekend, Liem confesses to Marcus that he loves him. Marcus replies that he knew Liem was gay. They get into a relationship together. Liem is taken by this new experience, and begins to imagine a new hopeful future for himself.

Besides trying to attain his cultural identity, Liem now begins to think about the new possibilities that he may attain only in America. He receives a letter from his father, but he is afraid to open it and read as this letter might make him bound to his life in Vietnam (his home country). He knows "his life would change again, and perhaps he wanted it to stay the same". He is sure "his father had written no more than what needed to be said: make money and send it home, take care and be good" (41). Still, he imagines a different future for himself. At the story's end, after reading his father's letter, in which he informs him that the Vietnamese are going to "erase the past and rebuild our glorious country," Liem does not recognize himself in the window:

When he raised his hand, his reflection raised its hand, and when he touched his face, the reflection did the same, and when he traced the curve of his cheek and the line of his jaw, so, too, did the mirror image. Why, then, did he not recognize himself? And why did he see right through himself to the dark street outside? (46)

(The Impact of Trauma on Vietnamese Refugees in ...)Dr Sherine Abdelghafar 
Liem then peers out through the window at two men walking by. Through he could not recognize himself, he was seen by the men outside: "for a moment there were only the three of them, sharing a fleeting connection." However, after the two men had passed, "he was still standing with his hand pressed to the window, wondering if someone, behind blinds and curtains, might be watching" (47). Though others can see him, Liem fails to recognize himself. Liem has converted into this OTHER MAN whom he does not know. He has lost his Vietnamese identity, but cannot gain the American identity either. Thus, he is lost between both cultures. Liem gains a feeling of homelessness. He feels as an outsider; he does not know who he is anymore.

Nguyen uses the character of Liem to represent some of the struggles acute refugees confront. The primary goal of Liem as a refugee is to survive. Once achieved, this aim is soon replaced by the general ambitions of life. Liem seeks life goals as anyone else, which only makes his disconnection from the normal life even more present.

In both stories, Thâp and Liem exemplify Kunz's acute refugees. Since they leave their homeland on a moment's notice, it seems they have given little notice to the consequences of their action. They have reached, as Kunz states, "midway to nowhere stage" (135).

\subsection{The Suffering of the Vietnamese}

Janoff-Bulman points out that, traumatic responses (including shame, doubt, or guilt) may destroy important beliefs, especially in one's own safety or one's view of

(The Impact of Trauma on Vietnamese Refugees in ...)Dr Sherine Abdelghafar 
oneself as decent, strong, and autonomous (19-22). The title story, "A Good Scent from a Strange Mountain," in Butler's collection, is narrated by a very old Vietnamese dying man named Dao. Through the point of view of Dao, Butler describes how different kinds of people have suffered because of the Vietnam War. Dao now lives in New Orleans with his family consisting of his daughter, her son-in-law, and his grandson. His daughter is still holding on to the Vietnamese traditions in an attempt to maintain her cultural identity. His son-in-law and grandson are involved in the murder of a fellow immigrant who supported the new Communist regime in Vietnam.

As Dao approaches death, he is visited by the ghost of Ho Chi Minh: his childhood acquaintance and a formal Vietnamese leader, who cannot rest peacefully. The narrator engages in several conversations with Ho in which they debate the way each one of them had chosen to deal with the war: Ho had been engaged in revolution and then war, while Dao became a 'Hào Háo Buddhist' (239). Dao has chosen to remain uninvolved and to commit himself to peace during the war years. He says, "I chose my path, . . ., so that thee might be harmony" (246). After he knows that his grandson is involved in a murder crime, he chooses to remain silent: "I will never say a word about my grandson. And perhaps I will be as restless as Ho when I join him. But that will be all right. He and I will be together again and perhaps we can help each other" (249). This connection between Dao (the narrator) and Ho as well as the way they share the experience of trauma supports Caruth's view that "history, like trauma, 
is never simply one's own, that history is precisely the way we are implicated in each other's traumas" (24).

Nguyen's "War Years," which incorporates autobiographical elements, is drawn from the lives of Nguyen and his parents. The story is narrated, in the first person, by the grown son of a Vietnamese refugee family who escaped Vietnam when the boy was very young. Like Nguyen, the narrator, who has grown up in a Vietnamese community in San Jose, California, feels caught between both cultures (the American and the Vietnamese). The boys' parents run a Vietnamese grocery store called the New Saigon Market. The narrator flashes back to a moment in the past when he was only thirteen years old.

One day, a woman named Mrs.Hoa shows up at the store asking for money to support the anti-communist forces in Vietnam who are training in Thailand. However, the boy's mother refuses to give her the money, thus leading Mrs. Hoa to warn her that people might think they are Communist sympathizers. Mrs. Hao leaves only to return after a few weeks to ask the boy's mother again for money. Still, the boy's mother refuses:

"I am not giving you any money." She continues, "I work hard for my money. What do you do? You're nothing but a thief and an extortionist, making people think they can still fight this war." (Refugees 65)

Just then, Mrs Hao begins to convince the other customers that the boy's family is communist sympathizers: 
You heard her, didn't you? She doesn't support the cause. If she's not a Communist, she's just as bad as a Communist. If you shop here, you're helping Communists. (65-66)

Afraid that this might hurt their business, the boy's mother and the boy decide to pay Mrs. Hao a visit. When they arrive at her door, they found her sewing uniform suits for the Vietnamese troops, and they learn that her family served in the military in Vietnam as she had lost her entire family to the war.

Mrs.Hao spoke without any change in inflection, clutching the box to her chest. "The Americans sent my younger son's division to Laos in 1972. He never returned. As for my eldest son, he was in the army, too. The Communists killed him. I Buried him in Bien Hoa in 1969. My daughter wrote to tell me the Communists scratched the eyes out of the picture on his grave. (69)

Mrs.Hao has no clue whether her husband and one of her sons are still alive. Hearing her story, the boy's mother sympathizes with her and decides to help her. She hands her two hundred dollars in order to support the army. On their way back home, the boy's mother gives her son a five dollar bill, points him toward the nearest 7-Eleven, and tells him, in English, "Go buy." She adds, "Anything you want." However, the boy is startled; he does not know what to choose:

(The Impact of Trauma on Vietnamese Refugees in ...)Dr Sherine Abdelghafar 
I left her on the sidewalk and went in, the fivedollar bill as sick as wax paper in my hand, remembering how my mother's lips moved whenever she used the fingers of one hand to count on the fingers of her other hand. The 7Eleven was empty except for the two Sikh men at the registers, who gave me bored looks and returned to their conversation. Disinfectant tinted the air. I ignored the bank of arcade games and the racks of comic books, even though the covers of Superman and Iron Man caught my eye and the electronic whirring of Pac-Man called to me. Past the cleaning products and canned soups was an aisle stocked with chips, cookies, and candy. I glanced down the aisle, saw the glint of gold foil on a chocolate bar, and froze. While the clerks chatted in a language I could not understand, I hesitated, yearning to take everything home but unable to choose. (72)

Nguyen shows that, though the future is in front of him and he is free to buy whatever he wants, the boy feels lost (in identity). It is such a complicated moment, as the boy is allowed for the first time to buy whatever he likes, but at the same moment he learns about the sad history of his home country. Nguyen here makes a point to show that the Vietnam War, even after it ended, can impact the lives of the refugees even those who were not directly involved or affected by it. 
Both stories seem to be dark; the politics of the war was not won. In fact, for those people who had lived through the war, it is not finished. It goes on for decades. Volkan emphasizes, "Refugees struggle with attempts to integrate the images of what was left behind with what they face in their new environment" ( 61).

\subsection{Loss of Memory}

Survivors of the Vietnam War may live with fragmented memory, a diminished sense of self, and a feeling of alienation (Herman 42-47). "The Trip Back" is told from the point of view of Khánh, a young Vietnamese man who moved from Vietnam to the United States. Khánh has made a fortune in the laundry and dry-cleaning business; he starts his narrative, saying: "I am just a businessman, not a poet. It is the poet who is supposed to see things so clearly and to remember. Perhaps it is only the poets who can die well. Not the rest of us" (Butler 29). Khánh is waiting for Mr.Chinh, his wife's grandfather at the airport. While driving to the airport, Khánh has observed the business fronts. This "commercial life . . . strikes him" (Wutz 498); he declares, "The little ones that seemed so Vietnamese to me in how the people always looked for some new angle, some empty corner in the marketplace" (Butler 30).

The grandfather is an old Vietnamese who is finally allowed to migrate to the United States. Khánh picks the grandfather up the airport, he is saddened to find out that the grandfather suffers from severe dementia. He can remember his own childhood as well as his past trips does not remember his

(The Impact of Trauma on Vietnamese Refugees in ...)Dr Sherine Abdelghafar 
granddaughter. Khánh is worried that, perhaps, he too will eventually end up like the grandfather, unable to remember his life. However, he does not realize that he had already suffered a loss of memory when he decided to leave his home country and forget about the Vietnamese traditional culture. Khánh is now a businessman, a symbol of the American dream. He is so engaged in his new business that he seems to forget the most important thing in his life: his family.

At the end of the story, Khánh decides to spend more time with his wife as he is afraid that one day he may wake up not knowing his wife. He says, "I could neither reassure her with a lie nor make her face the truth. But I had to do something. I had thought too much about this already. A good businessman knows when to stop thinking and to act instead" (43). Wutz concludes, "his [Khánh's] vivid memory bypasses the shield of commercial being he has been building and, instead, pushes to the surface the poetic self narrating the story." He adds, "He [Khánh] becomes vulnerable to nostalgia because his psychological material veneer or mental bulwark ultimately collapses" (498). After long years of denial, Khánh finally allows his memory of the trauma experience rise to the surface as if he was standing at the bottom of the sea: "I felt her breath on the side of my face as warm and moist as a breeze off the South China Sea" (Butler 43).

In "I'd Love You to Want Me," which is narrated in the third person, Nguyen portrays the story of Professor Khanh and his wife, Mrs. Khanh, a Vietnamese couple who fled to the United States as refugees after the war. Suffering from

(The Impact of Trauma on Vietnamese Refugees in ...)Dr Sherine Abdelghafar 
dementia, Professor Khanh mistakes his wife for another woman and begins calling her 'Yen'. At first, Mrs Khanh is upset by this incident but then she decides to stand by the side of her husband. She does not know who this woman is, but as the narrative proceeds, it is revealed that Yen was the Professor's lover in the past. This shows that the Professor is still attached to the past. He cannot escape his past. As the mind's state of the professor deteriorates, his children advise their mother to give up her job as a librarian to spend more time with her husband. At first, she refuses but them she gives in as she notices differences in the behavior of her husband. For example, one day he gives her a red rose, still addressing her as 'Yen' though he had never done something romantic like this before. On another day, he yells at her, which he had never done before.

Returning home from her last day at her job, she finds the Professor missing. She keeps looking for him all night, but to no avail. Thus, she returns home to find him sitting in his library. He looks at her frantically, and asks who she is, she replies: "It's just me. It's Yen" (Refugees 121). Thus, it seems Mrs. Hao is still a refugee, but in her own marriage. She pretends to be someone else in order to survive her marriage:

She wondered what, if anything, she knew about love. Not much, perhaps, but enough to know that what she would do for him now she would do again tomorrow, and the next day, and the day after that. She would read out loud, from the beginning. She would read with measured 
breath, to the very end. She would read as if every letter counted, page by page and word by word. (124)

For Mrs. Khanh, her refugee status fade into the background of her life. This exhibits "how human beings are complex: while large events can certainly shift a person's life dramatically, they are also not solely defined by a single experience, or by their cultural identity" (Emanuel). Both stories show the conflict which arises when people move from their traditional home country to a modern new one.

\subsection{The Other Side of America}

Vickroy argues, "Societies, communities, or families may want to preserve stability or be willing to sacrifice victims for other goals. However, individuals or circumstances within these same environments can be triggers for memory or encouragement because not everyone is silenced or traumatized by similar circumstances" (131). Butler's short story "Letters from My Father" and Nguyen's "Fatherland" depict family struggles.

"Letters from My Father" is about Fran, a mixed-race teenager who has grown up in Vietnam without her American father. Fran has a poor connection with her father because of troubles with immigration. They have been separated in two distant countries. Moreover, when she is finally reunited with her father, she has trouble connecting to a man she has only known through some photographs. The narrator and her father try to bridge the gaps in their relationships. However, she begins to feel that perhaps too

(The Impact of Trauma on Vietnamese Refugees in ...)Dr Sherine Abdelghafar 
many issues have come between her and her father. Prior to reuniting with her father, she had received letters from her father in which he tells her how much he loves her. However, once reunited, she begins to wonder if her father truly loves her. Still, she is certain that her father will always be by her side, and that he tried so hard to get her into the United States. She knows he will come back. Fran's story demonstrate that some refugees have to bear the loss of their families.

The letters become symbols of Fran's father's love to Fran. However, Fran revolts against this means of communication "as being wholly inadequate when confronting the problem of absence." Once she meets her father, she becomes disappointed by the letters as these letters which "intended to bridge the space between the two" now "serve instead to augment the disconnect that oddly unites them." Accordingly, Fran's early experience of trauma (of loss) "is refigured in the present lack of interpersonal connection and reflects the far grander scale of the devastation wrought by the war itself' (Wyman 94).

Nguyen's story "Fatherland" deals mainly with the issue of family relations and the complexity of Vietnamese identity. Narrated in the third person, the story centers on the character of Phuong, the oldest daughter of the second set of children of the Vietnamese Mr. Ly. Prior to his marriage to Phuong's mother, Mr.Ly had been forced to serve in the camp during the Vietnam War, leaving a wife and three children in Vietnam. However, his wife, the first Mrs.Ly, had fled to the United States with her children. After returning

(The Impact of Trauma on Vietnamese Refugees in ...)Dr Sherine Abdelghafar 
from the camp, Mr.Ly remarried and had three more children. He named those children after his first set of children. The eldest daughter of the first set of children, who called herself Vivien, is now a pediatrician. She decides to visit Vietnam and stay with her father and his family. When she arrives, Phuong is stunned by the glamorous appearance of Vivien:

Her first glimpse of Vivien ate the airport only confirmed the appropriateness of such a movie star's name for the young woman who paused at the terminal's glass gates, her eyes hidden behind enormous sunglasses, her lips slightly parted in a glossy pout, pushing a cart loaded with her own weight in crimson luggage. As she jumped and waved to get Vivien's attention, Phuong was thrilled to see that her sister bore utterly no resemblance to the throngs of local people waiting outside to greet the arrivals, hundreds of ordinary folk wearing drab clothes and fanning themselves under the sun. (Refugees 183)

She also notes that her father prefers Vivien over his other children. Phuong has grown up in Vietnam with the fantasy that this other American sister has lived the American dream.

Vivien invites her family to an expensive restaurant. In return, her family takes her to all the major tourist sites in Vietnam. Phuong realizes that, to the Americans, "We're all the same to them"; she "understood with a mix of anger and shame — small, charming, and forgettable" (193). During one

(The Impact of Trauma on Vietnamese Refugees in ...)Dr Sherine Abdelghafar 
of these trips, Vivien and Phuong grow closer to the extent that Vivien admits to her sister that she does not love her father as she does not know him. She says, "It's easy for him to love me. That's the way it should be. He remembers me. I don't remember him. Can you love someone you don't remember? Can you love someone you don't know?" (196). Furthermore, when Phuong asks her to sponsor her in America, she replies she cannot sponsor her. Then she reveals to Phuong that she lied to them about her life in America: she is a receptionist not a pediatrician, and is actually in debt. She confesses that she had to lie about the luxury of life in American in order to hide her family's struggle to be accepted as refugees in the United States. Vivien then returns to America, leaving Phuong in a state of shock.

Disillusioned, Phuong burns all the photos she and her family had taken with Vivien, with the ashes vanishing into the sky: "The photograph flared when she touched it with fire, Vivien's features melting before her own, their faces vanishing in flame" (207). This act represents Phuong's desire to make a new life, a life that is completely different than her sister's. The story concludes with Phuong resolving to find a way to escape Vietnam. Thus, as Vickroy reveals, "Traumatized characters are offered clues and bits of memories to reassess survival and finally engage in new ways of thinking and being" (131). 


\section{CONCLUSION}

In the stories scrutinized above, both Butler and Nguyen represent different characters who acutely exemplify Kunz's theory of acute refugees. The stories also follow the conventions of Caruth's trauma theory. The stories analyzed above tackle the lives of Vietnamese refugees who had escaped Vietnam and settled in the United States. These stories exhibit the cultural differences between the Americans and the Vietnamese. The refugees represented in the stories are quite aware of their own situation. The stories shed light on the issues of the refugees situation after fleeing their home country after the fall of Saigon and the challenges they face in the new country. Butler and Nguyen emphasize that, though the Vietnamese refugees do their best to adapt to their new home, they suffer from loss of identity. They are caught between both the American and Vietnamese cultures. Both authors use symbols such as the ghost, photos and letters to show that the refugees are still haunted to the past. Whether affected directly or not by the Vietnam War, the refugees become obsessed by the trauma experience no matter how long they try to deny it. These are such common symptoms of trauma.

(The Impact of Trauma on Vietnamese Refugees in ...)Dr Sherine Abdelghafar 


\section{Works Cited}

Baker, Reginald P. and David S North. The 1975 Refugees:

Their First Five Years in America. New Trans Century Foundation, 1984. Print.

Berger, James. "A War of Ghosts: Trauma Theories, Traumatic Histories, and the Middle East -

Book Review". Writing History, Writing Trauma, Reviewed by Dominic LaCapra. Tikkun 18.1 (2003): 72-76. Web. 4 Jan. 2018.

Butler, Robert Olen. A Good Scent from A Strange Mountain. New York: Grove Press, 1992. Print.

Caruth, Cathy. Unclaimed Experience: Trauma, Narrative, and History. Baltimore and London: John Hopkins University Press, 1996. Print.

Cole, Susan F., et al. Helping Traumatized Children Learn. Boston, Massachusetts Advocates for Children, 2009. Print.

Dawkins, Laura. "The Link of Our Yearning Hands:

Trauma and Community in Robert Olen Butler's $A$ Good Scent from a Strange Mountain." Short Story 17. 1 (2009): 34-47. Print.

(The Impact of Trauma on Vietnamese Refugees in ...)Dr Sherine Abdelghafar 
Eder, Richard. "Review of A Good Scent from a Strange Mountain." Los Angeles Times Book Review. 29 March 1992. Web. 15 March 2018.

Emanuel, Lizzy. "The Refugees Themes: War and the Refugee Experience.” LitCharts LLC. 5 Jan. 2019. Web. 9 June 2019.

Espiritu, Yen Lê. "Thirty Years AfterWARd: The Endings That Are Not Over." Amerasia Journal 31.2 (2005): xiii-xxiii. Print.

Freud, Sigmund. Beyond the Pleasure Principle. Translated and Edited by James Strachey. New York: W.W. Norton \& Company. 1961. Print.

Gale, Cengage Learning. A Study Guide for Robert Olen Butler's A Good Scent from a Strange Mountain. Gale Group. 2001. Print.

Harper, Douglas. 2020. "Refugee." Online Etymology

Dictionary, n.d. Web. 16 Nov. 2018.

Herman, Judith. Trauma and Recovery. New York: Basic. 1992. Print.

Janoff-Bulman, Ronnie. Shattered Assumptions: Toward New Psychology of Trauma. New York: Free Press, 1992. Print.

(The Impact of Trauma on Vietnamese Refugees in ...)Dr Sherine Abdelghafar 
Kunz, E. F. "The Refugee in Flight: Kinetic Models and Forms of Displacement." The International Migration Review 7.2 (1973): 125-46. Web. 2 Jan. 2018.

Nguyen, Viet Thanh. Interview by Leonard Lopate. "Viet Thanh Nguyen's Stories of Refugees." Leonard Lopate Show, 27 Sep. 2018. Web 30 Dec. 2019.

---. Interview by Jon Wiener. "Call Me a Refugee, Not an Immigrant." The Nation. 11 June 2018. Web. 25 May 2019.

---. The Refugees. New York: Grove Press, 2017. Print.

---. Nothing Ever Dies: Vietnam and the Memory of War.

London: Harvard UP, 2016. Print.

---. "Just Memory: War and the Ethics of Remembrance."

American Literary History, (2013): 1-20. Print.

---. "Speak of the Dead, Speak of Viet Nam: The Ethics and

Aesthetics of Minority Discourse." The New Centennial Review. 6.2 (2006): 7-37. Print.

Stocks, Claire. "Trauma Theory and the Singular Self:

Rethinking Extreme Experiences in the Light of CrossCultural Identity." Textual Practice 21.1 (2007): 7192. Print.

UNHCR. Protecting Refugees. Cyprus: UNHCR Office, 2017. Web. 30 March 2018.

(The Impact of Trauma on Vietnamese Refugees in ...)Dr Sherine Abdelghafar 
Vickroy, Laurie. 2014. "Voices of Survivors in Contemporary Fiction." Contemporary Approaches in Literary Trauma Theory. Edited by Michelle Balaev. Palgrave MacmillaVickroyn. 2014: 130-51. Print.

"Viet Thanh Nguyan discusses The Refugees." Library

Podcast. Seattle Public Library and Foundation, 2017. Web. 25 Feb. 2018.

Volkan, Vamik D. Immigrants and Refugees: Trauma, Perennial Mourning, Prejudice, and Border Psychology. London: Karnac Books Ltd, 2017. Print. Wutz, Michael. "The Politics of (Post)Modern Form:

Tradition, Language, and Narrative Coherence in 'A Good Scent from a StrangeMountain." Amerikastudien / American Studies 52.4 (2007): 495-516. JSTOR. Web. 2 Jan. 2019.

Wyman, Sarah. "Facing Problems of Representation in Robert Olen Butler's 'Open Arms' and 'Letters from My Father."” Amerikastudien / American Studies 57.1 (2012): 91-113. JSTOR. Web. 2 Jan. 2019.

(The Impact of Trauma on Vietnamese Refugees in ...)Dr Sherine Abdelghafar 
تأثير الصدمة علي اللاجئين الفيتناميينن في مجموعة القصص للروائي رويرت أولن باتلر بعنوان رائحة طيبة من جبل غريب (ra 9 1 ) و مجموعة القصص

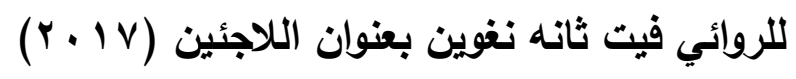

\section{ملخص}

بعد انهيار الحكومة الفيتنامية الجنوبية ، فر آلاف الأشخاص. وفي أواخر الثمانينات وأوائل التسعينيات ، شق العديد من المهاجرين طريقهم إلى الولايات المتحدة هربا من ظروف لا يمكن تحملها في بلدانهم وسعيا وراء حياة أفضل. كانت هنالك ثلاث موجات من الهجرة الفيتنامية. و الموجة الثالثه التي ظهرت بعد عام ra19 ا هي الأكثر شهرتا وتعقيدا حيث تضمنت العديد من اللاجئين الفيتتاميين المختلفين عن بعضهم البعض. بهرف هذا البحث الي دراسة التحديات التي واجهها اللاجئون الفيتتاميون في الولايات المتحدة. سيعالج هذا البحث بعض القصص القصيرة المختارة من كلا من مجموعة القصص القصيرة بعنوان رائحة طيبة دن جبل غريب (199 (1) للروائي روبرت أولن باتلر ومجموعة القصص القصيرة بعنوان اللاجئون (Y V V V للروائي فيت ثانه نغوين في ضوء نظرية الصدمة لدى اللاجئين. كانت حرب فيتتام حربًا فريدة في التاريخ مما دعي إلى تمثيلها بطريقة متميزة في الأدب. ترتبط القصص في هاتين المجموعة بالتجربة المشتركة للشخصيات التي نجت من الحرب في فيتام ووجدت طريقها إلى أمريكا. يقدم كلا من باتلر ونغوين مجموعة منتوعة من من الثخصيات - البعض منهم من الفيتتاميون والبعض الآخر أمريكيون ، لكن معظمهم من الفيتتاميين-الأمريكيين. من خلال القصص المختلفة للشخصيات ، كرن

(The Impact of Trauma on Vietnamese Refugees in ...)Dr Sherine Abdelghafar 
يستكثفا باتلر ونجوين مسئلتي الهجرة والهوية. ويركزا على ما يشعر به اللاجيء وما يعنيه أن يكون لاجنًا. إلى جانب ذلك ، يظهر كلا منهما الطرق المختلفة التي يستجيب بها اللاجئون لتجاربهم الناتجة عن تعرضهم للصدمة. الكلمات المفتاحية: سايغون - لاجئون فيتناميون - نظرية الصدمة - الهوية

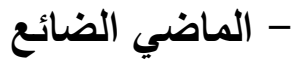

